\title{
FLAXSEED AS A SOURCE OF FUNCTIONAL INGREDIENTS
}

\author{
M. Rubilar ${ }^{1,2^{*}}$, C. Gutiérrez ${ }^{1,2}$, M. Verdugo ${ }^{1}$, C. Shene ${ }^{1,2}$, J. Sineiro ${ }^{3}$ \\ ${ }^{1}$ Scientific and Technological Bioresource Nucleus, Centre of Food Biotechnology and \\ Bioseparations, Universidad de La Frontera. Francisco Salazar 01145, Temuco, Chile. \\ ${ }^{2}$ Centre for Agri-aquicultural Nutrition Genomics (CGNA). Technology and Processes Unit. \\ Universidad de La Frontera. Francisco Salazar 01145, Temuco, Chile. ${ }^{3}$ Superior Technical School \\ of Engineering (ETSE). Universidad de Santiago de Compostela. Rúa Lope Gómez de Marzoa \\ s/n, 15782 Santiago de Compostela, Spain. *Corresponding author: mrubilar@ufro.cl
}

\begin{abstract}
Scientific evidence supports flaxseed consumption; however, a large sector of the population is still unaware of the benefits associated to its consumption and its possible applications as functional food ingredient in foodstuffs. Flaxseed is mainly known by its high alpha-linolenic acid content, but it is also a lignan source, soluble fibre and protein, compounds which are biologically active in the prevention of some non-transmissible chronic diseases. Southern Chile has comparative advantages for the cultivation of this crop. Together with its full processing, this crop could strengthen regional industry. The purpose of the present review is to highlight the nutritional properties of flaxseed.
\end{abstract}

Keywords: Flaxseed, oil, protein, mucilage, lignans.

\section{INTRODUCTION}

Flax (Linum usitatissimum) is an annual plant of the linaceae family. This plant grows to a height up to $60 \mathrm{~cm}$, with slender and very fibrous stems, lanceolate leaves having three veins, up to $4 \mathrm{~cm}$ long and $4 \mathrm{~mm}$ wide, and its bright blue flowers are up to $3 \mathrm{~cm}$ in diameter. The fruit contains a seed known as flaxseed or linseed (Pradhan et al. 2010).

Humans have consumed flaxseed since the beginnings of the earliest civilizations. It was used for medical purposes in ancient Egypt and Greece, mainly to relieve abdominal pains and also as energy source (Oplinger et al. 1989). Today, it is cultivated in more than 50 countries, the majority of them in the northern hemisphere. Canada is the main flax producer, followed by China, United States and India. In Chile, its production is very small. Most seed, imported from Canada, is consumed either as diet supplement or as an ingredient in prepared food.

Until a few years ago, flax was cultivated in Los Lagos Region, Southern Chile, mainly as raw material for textile industry. Today, flax is cultivated in Araucanía Region for oil extraction. Studies have shown that crop yield is higher in this Region, because of its soil and climate characteristics. Flax is best suited for fertile, fine textured, and loamy soils: An important factor is the amount of rainfall during the growing period. Adequate moisture and relatively cool temperatures, particularly during the period from flowering to maturity, seem to favour both oil content and oil quality. Flaxseed is the seed with the highest 
Omega 3 fatty acid (alpha-linolenic acid) content. Around $48 \%$ of all the lipids correspond to this essential fatty acid that should be consumed in a normal diet (Coskuner and Karababa 2007).

Flax is considered a functional food or source of functional ingredients, because it contains alpha-linolenic acid (Bozan and Temelli, 2008), lignans and polysaccharides (other than starch), all of which have positive effects in disease prevention. Although scientific evidence supports flaxseed consumption, many people are still unaware of the benefits provided by this product and its possible applications in the production of foodstuffs (Udenigwe, et al., 2009). The purpose of the review presented here is to highlight the nutritional properties of flaxseed in view to the fact that Southern Chile has comparative advantages for this crop production.

\section{Chemical flaxseed composition}

The seed contains approximately $40 \%$ lipids, $30 \%$ dietary fibre and $20 \%$ protein. The chemical composition varies considerably among varieties and also depends on the environmental conditions in which the plant is grown. Cotyledons contain $75 \%$ of the lipids, and $76 \%$ of protein is found in the seed. The endosperm contains only $23 \%$ of the lipids and $16 \%$ of protein (Daun et al., 2003; Oohma, 2003). Table 1 shows the chemical flaxseed composition.

Table 1. Chemical composition of flaxseed.

\begin{tabular}{cccccc}
\hline Humidity \% & Protein \% & Lipids \% & Fibre \% & Ash \% & Reference \\
\hline 7.4 & 23.4 & 45.2 & - & 3.5 & Mueller et al. (2010) \\
$4-8$ & $20-25$ & $30-40$ & $20-25$ & $3-4$ & Coskuner and Karababa (2007) \\
\hline
\end{tabular}

Lipid flaxseed composition makes it an important source of Omega 3 fatty acids, especially $\alpha$-linolenic acid (ALA) which may constitute up to $52 \%$ of the total fatty acids. Furthermore, flaxseed is an important source of phenolic compounds, known as lignans, a colloid gum, and protein of high quality. Although these compounds are located in different parts of the seed, they interact during oil extraction and processing. Thus, its processing presents serious challenges (Oomah, 2003).

\section{Lipids}

The principal component of flaxseed is its

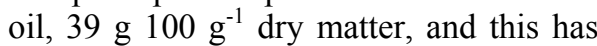
been the object of its processing (Daun et al., 2003; Oomah, 2003) for years. Cotyledons are the tissue in which oil is mainly stored, containing the highly sought-after $\alpha$-linolenic, linoleic and oleic acids. Flaxseed oil is mainly found as triacylglycerols $\quad(98 \%)$ with lower contents of phospholipids $(0.9 \%)$ and free fatty acids $(0.1 \%)$ (Mueller et al. 2010).

Oil extraction yield and fatty acid content (linolenic acid, omega 3; linoleic acid, omega 6; oleic acid, omega 9) vary slightly between authors, and both would be dependent on oil extraction technology (Table 2).

\section{Protein}

The average protein content in flaxseed is

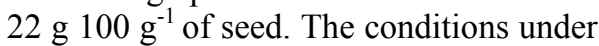
which seed is processed, that could be dehusked or defatted, affect the protein content of the product. The 
Table 2. Extraction yield and Omega 9, Omega 6 and Omega 3 contents of flaxseed oil extracted by various methods.

\begin{tabular}{|c|c|c|c|c|c|}
\hline $\begin{array}{l}\text { Oil yield } \\
(\%)\end{array}$ & $\begin{array}{l}\text { Method of } \\
\text { extraction }\end{array}$ & $\begin{array}{l}\text { Linolenic } \\
\text { Acid (\%)* }\end{array}$ & $\begin{array}{c}\text { Linoleic } \\
\text { Acid (\%)* }\end{array}$ & $\begin{array}{c}\text { Oleic } \\
\text { Acid (\%)* }\end{array}$ & Reference \\
\hline 40.3 & $\begin{array}{l}\text { Soxhlet with } \\
\text { petroleum ether }\end{array}$ & 49.3 & 14.7 & 24.1 & $\begin{array}{l}\text { Oplinger, et al. } \\
(1989)\end{array}$ \\
\hline 66.7 & & 55.762 & 15.810 & 16.762 & $\begin{array}{l}\text { Zhang et al. } \\
(2008)\end{array}$ \\
\hline- & $\begin{array}{l}\text { Extraction with } \\
\text { chloroform/methanol } \\
\text {. assisted by } \\
\text { ultrasound }\end{array}$ & 46.15 & 16.57 & 23.67 & $\begin{array}{l}\text { Metherel et al. } \\
(2009)\end{array}$ \\
\hline 45.2 & $\begin{array}{c}\text { Soxhlet with } \\
\text { petroleum ether }\end{array}$ & - & - & - & $\begin{array}{l}\text { Mueller et al. } \\
(2010)\end{array}$ \\
\hline 38.8 & $\begin{array}{c}\text { Supercritical } \\
\text { extraction with } \mathrm{CO}_{2}\end{array}$ & 50.0 & 14.4 & 16.1 & $\begin{array}{l}\text { Pradhan, et al. } \\
(2010)\end{array}$ \\
\hline 27.6 & $\begin{array}{c}\text { Extraction with } \\
\text { Methanol/ammonia/ } \\
\text { hexane }\end{array}$ & 18.46 & 38.46 & 31.56 & Oomah, (2001) \\
\hline
\end{tabular}

*As a proportion of total extracted fatty acids

husk has a low protein content; because of this, meal production from dehusked and defatted seeds gives an isolate with high protein content. In flax, as in other seeds, globulins are the main proteins, they make up $18.6 \%$ of the total protein, while albumin content represents $17.7 \%$ of the total protein. Flax protein is relatively rich in arginine, aspartic acid and glutamic acid, and the limiting aminoacids are lysine, methionine and cysteine (Chung et al., 2005).

\section{Fibre}

Fibre, the component which gives volume and form to the majority of foodstuffs, is not hydrolyzed in the digestive tract; during the digestion process, fibre retains water and impedes cholesterol absorption. There are two types of fibre, soluble and insoluble: insoluble fibre is composed of substances such as cellulose, hemicellulose and lignin. Whole-grain cereals present the greatest quantity of this type of fibre. Soluble fibre forms a gel in the presence of water, and this complex includes gums, pectins and sugars which form mucilage $(8 \%$ dry weight of flaxseed). Flax contains polysaccharides (other than starch) which, due to their anti-hypercholesterolemic, anti-carcinogenic and glucose metabolism controlling effects, may prevent or reduce the risk of various important diseases, such as diabetes, lupus nephritis, arteriosclerosis and hormone-dependent types of cancer (Bilek and Turhan, 2009; Williams et al. 2007). Lucas et al. (2004) found a reduction of cholesterol in the plasma and arterosclerotic lesions after the incorporation of flax mucilage and $\alpha$ linolenic acid into diet. Likewise, antibacterial and fungistatic activities of oligosaccharides extracted from the seed has been reported (Guilloux, et al., 2009); these activities can control the growth of pathogens affecting the agricultural sector, such as Alternia solani and Alternia alternata; the human pathogen Candia albicans; and the deterioration of 
foodstuffs by fungi Penicillium chrysogenum, Fusarium graminearum and Aspergillus flavus (Xu et al. 2008).

\section{Lignans}

One of the most interesting characteristics of flaxseed is its content of complex phenols, such as lignans. The most remarkable one is secoisolariciresinol (SDG), although isolariciresinol, pinoresinol, mataresinol and other derivatives of ferulic acid are also present (Daun et al., 2003). Lignan consumption reduces cardiovascular risk and inhibits the development of some types of diabetes (Mueller et al. 2010). Health benefits of flax lignans reside in their antioxidant capacity as sequestrators of hydroxyl radicals, and as estrogenic compounds due to their structural similarity to $17-\beta$-estradiol. The antioxidant capacity of SDG is related to the suppression of the oxidant conditions due to oxygen species. SDG diglycoside and its aglycone, secoisola-riciresinol display a very high antioxidant capacity and act as protectors against damage to DNA and liposomes - especially in the epithelial cells of the colon exposed to these compounds - during the metabolism of colon bacteria which transform them into mammal lignans (Rajesha et al. 2006; Hu et al. 2007).

\section{CONCLUSION}

Although flaxseed has been well known since ancient times, at present it is not massively used in the formulation of foodstuffs; however its popularity has increased thanks to recent studies. Flaxseed contains important quantities of compounds with functional and bioactive properties, such as alpha-linolenic acid, lignans, soluble fibre and protein, whose effects on the prevention of certain non- transmissible chronic diseases have been tested. These characteristics make flaxseed an attractive source of functional ingredients for the preparation of foodstuffs.

\section{ACKNOWLEDGEMENTS}

The authors are grateful for financing from Fondecyt Project 1090516 and projects of the Research Directorate of UFRO, Convenio de Desempeño I and II 2009; and to GAP technical support staff.

\section{REFERENCES}

Bilek, E., Turhan, S. 2009. Enhancement of the nutritional status of beef patties by adding flaxseed flour. Meat Sci. 82, 472-477.

Bozan, B., Temelli, F. 2008. Chemical composition and oxidative stability of flax, safflower and poppy seed and seed oils. Bioresource Technol. 99, 6354-6359.

Coskuner, Y., Karababa E. 2007. Some physical properties of flaxseed (Linum usitatissimum L.). J. Food Eng. 78, 1067-1073.

Chung, M., Lei, B., Li-Chan, E. 2005. Isolation and structural characterization of the major protein fraction from NorMan flaxseed (Linum usitatissimum L.). Food Chem. 90, 271-279.

Daun, J., Barthet, V., Chornick, T., Duguid, S. 2003. Structure, composition, and variety development of flaxseed. In: Thompson, L., Cunanne, S. edition. Flaxseed in Human Nutrition. 2nd edition Champaign, Illinois. pp. $1-40$.

Guilloux, K., Gaillard, I., Courtois, J. Courtois, B., Petit, E. 2009. Production of Arabinoxylan-oligosaccharides from Flaxseed (Linum usitatissimum). J. Agr. Food Chem. 57, 11308-11313.

Hu, C., Yuan, V., Kitts, D. 2007. Antioxidant activities of the flaxseed lignan secoisolariciresinol diglucoside, its aglycone secoisolariciresinol and the mammalan lignans enterodiol and enterolactone in vitro. Food and Chem. Toxicol. 45, 2219-2227. 
Lucas, E., Lightfoot, S., Hammond, L., Devareddy, L., Khalil, D., Daggy, B., Smith, B., Westcott, N., Mocanu, V., Soung, D., Arjmandi, B. 2004. Flaxseed reduces plasma cholesterol and atherosclerotic lesion formation in ovariectomized Golden Syrian hamsters. Atherosclerosis. 173, 223-229.

Metherel, A., Taha, A., Izadi, H., Stark, K. 2009. The application of ultrasound energy to increase lipid extraction through put of solid matrix samples (flaxseed). Prostag Leukotr Ess $81,417-423$

Mueller, K., Eisner, P., Yoshie-Stark, Y., Nakada, R., Kirchhoff, E. 2010. Functional properties and chemical composition of fractionated brown and yellow linseed meal (Linum usitatissimum), J. Food Eng. 98(4), 453460 .

Oomah, B. 2001. Flaxseed as a functional food source. J. Sci. Food Agr. 81, 889-894.

Oomah, B., 2003. Processing of flaxseed fiber, oil, protein, and lignan. In:Thompson, L., Cunnane, S. Editores. Flaxseed in Human Nutrition. $2^{\text {nd }}$. Edn. Champaing, Illinois. 363386.

Oplinger, E., Oelke, E., Doll, J., Brundy, L., Schuler, R. 1989. Flax. Alternative Field Manual. University of Winsconsin-Extension corporative extension St. Paul. USA, 114-126.
Pradhan, R., Meda, V., Rout, P., Naik, S., Dalai, A. 2010. Supercritical $\mathrm{CO}_{2}$ extraction of fatty oil from flaxseed and comparison with screw press expression and solvent extraction processes. J. Food Eng. 98(4), 393-397.

Rajesha, J., Murthy, K., Kumar, M., Madhusudhan, B., Ravishankar, G. 2006. Antioxidant potentials of flaxseed in vivo model. J. Agr._Food Chem. 54, 3794-3799.

Udeniqwe, C., Lu, Y., Han, C., Hou, W., Aluko, R. 2009. Flaxseed protein-derived peptide fractions: Antioxidant properties and inhibition of lipopolysaccharide-induced nitric oxide production in murine macrophages. Food Chem. 116, 277-284.

Williams, D., Verghese, M., Walker, L., Boateng, J., Shackelford, L., Chawan, C. 2007. Flax seed oil and flax seed meal reduce the formation of aberrant crypt foci (ACF) in azoxymethane-induced colon cancer in Fisher 344 male rats. Food Chem. Toxicol. 45, 153-159.

Xu, Y., Hall, C., Wolf-Hall, C. 2008. Antifungal Activity Stability of Flaxseed Protein Extract Using Response Surface Methodology. J. Food Sci. 73(1), 9-14.

Zhang, Z., Wang, L., Li, D., Jiao, S., Chena, X., Maoa, Z. 2008 . Ultrasound-assisted extraction of oil from flaxseed. Sep. Purif. Technol. 62, 192-198 